\title{
TOURISM POLICY IN LATVIA - FROM A TOP-DOWN TO A COLLABORATIVE APPROACH
}

\author{
Maija Rozite \\ Turiba University, Latvia \\ Aija van der Steina \\ University of Latvia, Latvia \\ Ilona Kalnina \\ Ministry of Economics of Latvia, Latvia
}

\begin{abstract}
In 2019, Latvia drafted a National Development Plan [NDP 2027] for the next period, which also comprises actions for the development of the tourism sector. Unlike previous practices, approaches to drafting a common plan and developing and implementing tourism policy have changed significantly.

The aim of the research is to describe the process of developing a tourism development plan, analyse the use of the latest planning and policy implementation approaches and evaluate the framework of the plan.

A qualitative research strategy - a case study was used. The main research methods are document analysis, in-depth interviews and participatory observations.

The process of drafting a new tourism policy and action plan, its main stages, tasks, methods, key stakeholders and discussions and the various documents elaborated has been summarized as a result of the research. The main problems related to the implementation of a bottom-up collaborative approach - lack of competencies of individual stakeholders, dominance of municipal interests, conviction that problems can only be solved from above, centrally, using state budget resources - have been identified.

The document analysis shows that the tourism policy document drafted differs significantly from previous documents. It incorporates the need for collaboration between tourism destinations, local municipal organizations and defines productivity as a transversal criterion for action.
\end{abstract}

Keywords: collaborative approach, destination cooperation, implementation, tourism policy.

\section{Introduction}

The tourism industry is a sector in which change is taking place very rapidly, both because of its internal complexity and its very close links to various external, including global, processes. Any country wishing to remain internationally competitive must develop a long term tourism development policy. 2018-2020 in Latvia was marked by the development of several important development documents, including The National Development Plan 2021-2027 [NDP 2027]. 
The plan is being developed in the context of the projection of the European Union's financial and investment needs for the next period. In parallel, work was begun on administrative-territorial reform. In order to ensure the effective implementation of NDP 2027, development policies of sectoral ministries are also being developed. Already at the end of 2018, the Ministry of Economics [MoE] started developing the draft Tourism Development Plan [TDP]. Unlike previous tourism policy development processes (e.g. The Tourism Development Guidelines 2014-2020 (MoE, 2013), the structure of the intended document, the approaches used and the degree and order of stakeholder involvement in the development process differed.

The aim of the research is to describe the process of developing a tourism development plan, analyse the use of the latest planning and policy implementation approaches and evaluate the framework of the plan. New knowledge in tourism planning and policies are developed not just by analysing documents. They are formed depending on how problems are identified, what approaches and methods are used, and what guidelines are developed (Hall, 2011; Dredge \& Jamal, 2015). Defining the most appropriate tourism policy is a major challenge for politicians, private and public actors alike, considering tourism as an economic phenomenon and the number of players involved in it (Manente, Minghetti, \& Montaguti, 2013).

The qualitative research strategy was chosen to carry out the research - the analysis of the development process in one case, i.e. the Tourism Development Plan. As the authors of the research participated in the planning process, this research uses the participatory action approach. The document analysis, a semistructured interviews were used as the main methods for obtaining primary data.

\section{Literature review}

\section{Approaches to tourism planning and implementation}

Although the implementation of tourism policy development and plans is extremely important, relatively little research has been conducted on it (Hall, 2008). Policy implementation is perceived as a process, an interaction between policy, set goals and actions to achieve the goals. They are a multi-layered process that distinguishes three different approaches: 'top down' or 'top down rational', 'bottom up' and 'interactive' (Hall, 2008; Hall, 2009). The interactive approach is also described as the 'collaborative', 'cooperative' approach (Panyik \& Anastasiadou, 2013). The top down approach is the implementation of policies where decision-makers are at a higher level of hierarchy and those implementing at lower levels. This approach is criticized, as policy makers do not see what is happening at the lower level. In such cases, there is a clear distinction between policy making and implementation. The bottom-up approach involves those who 
really implement policies - stakeholders, non-governmental organizations and the public - and stresses the importance of public-private partnerships. It seeks policy tools and instruments to address the problems of lower level implementers. The disadvantage of the bottom-up approach is that the policies pursued do not always achieve the goals that should be achieved at the strategic level. The third, interactive or collaborative approach, is described as a complex process of negotiation and bargaining between political actors and planning and policymaking at all levels. Such an approach is the closest to real processes, where both formal and informal networks are used and involved in policy-making, and where political forces manifest themselves. Though it is acknowledged that the outcome of the policy depends on the outcome of the agreement and a continuous process. As a result, it is more difficult to objectively measure achievement, and not always possible to clearly define the outcome (Hall, 2008).

\section{Tourism policy and state governance}

Tourism governance (Hall, 2011) is described as a means of addressing the social, economic, political and environmental challenges of tourism development at a time when the role of the state is changing, dominated by neo - liberal ideas, supranational structures (e.g. the European Union, UN World Tourism Organization) and the increasing role of various non-governmental organizations. New governance is the adjustment of a country to the economic and political environment and how it operates. These are administrative measures that do not occur solely in state institutions. New forms of governance are evolving, characterized by diversity and decentralization, deliberation, flexibility and revisability, experimentation and knowledge creation (Hall, 2011). Hall's concept of governance is defined as: "The core concept of governance in public policy terms is the relationship between state intervention (public authority) and societal autonomy (self-regulation)" (Hall, 2011, 442).

State intervention in tourism industry development focuses on strengthening demand, supply and tourist destinations in the national economy. Public authorities manage tourism through regulatory documents and direct oversight of real processes. An important area today is public-private partnerships, which combine economic (financial) activities and organizational relationships between public and private organizations. Panasiuk (2019) emphasizes that one of the more modern forms of governance is regional and local tourism organizations. The importance of deregulation in tourism governance is growing with less regulatory documents and more management freedom. The role of the state has changed in the last decade, moving from a simple model of public administration to a model that emphasizes efficiency, return on investment, and the role of markets and stakeholders (Liu, Tzeng, \& Lee, 2012).

The main principles of the European Union's [EU] tourism policy were defined in 2010 (EC, 2010). Principles such as maximizing the potential of 
financial resources and instruments, and product innovation are important in the new planning period as well. The new European Parliament and Council Regulation (EC, 2018) defines five policy objectives aimed at making Europe greener, smarter, more connected, more socially responsible and closer to its citizens. A European policy closer to the citizen means the sustainable and integrated development of urban, rural and coastal areas through local initiatives.

The EU tourism policy is dominated by the principle of subsidiarity (decisions at the closest level possible; synchronization of actions). Not only can it be used at lower levels, but also to coordinate actions, resources and stakeholders at different levels, both horizontally i.e. within destinations, and vertically - in tourism product development, as well as in cross-border cooperation (Panyik \& Anastasiadou, 2013).

The national tourism policy is reflected in organizational tools such as development plans, programmes, strategies that identify key challenges and directions (Panasiuk, 2019).

\section{Methodology}

This research uses a qualitative approach. The research strategy is based on a single case study where multiple sources of evidence are used. Case study is an appropriate method for empirical research, as the method helps reveal "real - life complexities of managing organisations and destinations" (Altinay \& Paraskevas, 2008, 77). In this case, the choice of a single case study and not a multiple-case study relates to the fact that researchers had the opportunity to participate and observe processes themselves and access to data, which is most often restricted.

As the authors of the paper participated in the development of the tourism development plan, the research uses the action or participatory action research approach, which Winter \& Munn-Giddings $(2001,8)$ define as "the study of a social situation carried out by those involved in that situation in order to improve both their practice and the quality of their understanding". Using this approach, researchers are members of a group (Altinay \& Paraskevas, 2008) using a practice-based and "experiential learning approach” (O`leary, 2004, p. 141) and "orientation and purpose is on enquiry rather than a research methodology" (Koshy, Koshy, \& Waterman, 2010, 4).

Various types of data were used in the research - document analysis, participatory observations and formal and informal interviews.

Document analysis of the tourism development plan included documents related to planning process organisation (invitations, lists of participants), transcripts and visual materials of focus groups, meeting minutes, reports produced during planning process, previous tourism development plans and drafts and the final version of new tourism development plan. 
Semi - structured face-to-face and phone interviews were conducted with researchers/ planning experts $(\mathrm{n}=3)$ and tourism representatives from a governmental institution $(\mathrm{n}=2)$ responsible for tourism planning.

\section{Research Results}

\section{NDP 2027 and tourism policy}

The National Development Plan 2021-2027 will be the main national midterm policy document in Latvia. It has been developed within the framework of the Sustainable Development Strategy of Latvia until 2030 (Saeima, 2010) and the 2030 Agenda for Sustainable Development Goals (UN, 2015). NDP 2027 sets strategic goals that Latvia expects to achieve by 2027, outlines sectoral policies and key reforms. It sets out investment areas for the state budget, EU funds and other financial instruments in Latvia.

The development of NDP 2027 was started in 2017 with detailed analytical work to assess the current situation, global trends and the previous plan. During the development process, it was found that the existing development policy (policy documents) system does not meet the strategic objectives set by the priority sectoral policies. The fragmentation and separation of the policy document from processes influencing them does not ensure balanced development, especially in the regions. The tourism industry with its multidisciplinary nature requires cross sectoral solutions. The Tourism Development Guidelines 2014-2020 (MoE, 2014) focused on actions to be implemented primarily within the scope of the MoE. A major challenge for tourism policy makers is the observance of principles of coherence and continuity.

According to the Cross-Sectoral Coordination Centre [CSCC], the institution responsible for NDP 2027, a smaller set of high-level documents can provide more effective and coherent planning for the new period. This new approach also concerns tourism policy. The principle of the sectoral approach was abolished and economic growth is measured using factors increasing values in the country. The Conclusions of the Council of the European Union (Council, 2019) on the tourism sector as a driver for sustainable growth, jobs and social cohesion for the next decade were also taken into account in the development of the new tourism policy.

In cooperation with CSCC experts, tourism policy has been integrated into the National Industrial Policy [NIP] framework at the strategic level, and a Tourism Development Plan is being developed to define specific policy implementation actions.

Analysing the previous tourism guidelines implementation results (MoE, 2017), it has been observed that the average daily expenditure of a foreign overnight traveller has decreased significantly despite the increase in the number of tourists. It was concluded that there is a need to promote the competitiveness 
and quality of Latvian tourism products and to create new and innovative high value added tourism products to ensure a longer stay and higher tourist receipts. Business tourism, health tourism (including exports of medical services) and cultural and nature tourism are still defined as the most competitive types of tourism.

The Latvian regional tourism offer is fragmented, homogeneous and includes the satisfaction of needs basically unrelated to tourism. It is often offered not as a comprehensive offer and does not cover a larger scale - tourist destination. Therefore the tourists are not interested in staying for a longer period. The development of regional tourism requires, firstly, the optimization of tourism management, tailored to the needs of tourist destinations, and, secondly, the promotion of new products for export and domestic tourists.

The use of various technological solutions in tourism product development is a topical issue in the industry. Development trends in new technologies show that smart tourism is becoming a necessity. It is therefore essential to promote the development of tourism in the following areas: smart solutions for tourism and destination development, digitalisation of tourism enterprises, digital solutions for global integration of the tourism industry and production of tourism statistics.

\section{Planning process and results}

In the second half of 2018, the MoE started the tourism planning process for the new planning period. It was implemented in four phases: (1) Situation analysis or pre-research phase; (2) Discussion of issues and development of proposals with industry stakeholders; (3) Elaboration, debate and improvement of the tourism development plan; (4) Coordination of the tourism development plan with other governmental bodies. Table 1 shows the planning process, the activities carried out, the actors involved and the main results.

The pre-research phase was done by engaging tourism researchers to carry out desk research. It used international and local statistics, studies, policy documents, forecasts, etc. Four thematic blocks were identified for the research by the MoE - enhancement of Latvian tourism supply for international markets, including development of health, business and cultural tourism in the context of higher added value; development of domestic and international tourism, regional tourism development; technological and digital solutions in tourism; tourism governance at the national and regional level. The pre-research phase resulted in an analytical report on tourism industry development (MoE, 2019a), which described the current situation, highlighted the strengths, development potential, weaknesses and possible solutions for each area. It highlighted areas and issues requiring stakeholder input and deeper discussion. Due to limited funding, only 
one primary research on the impact and results of state support instruments on tourism was carried out during the pre-research phase.

Table 1 Planning Process of the Tourism Development Plan 2021-2027

(created by the authors)

\begin{tabular}{|c|c|c|c|}
\hline $\begin{array}{c}\text { Planning phase } \\
\text { and duration }\end{array}$ & Activities and methods & Participants (stakeholders) & Results \\
\hline \multirow[t]{2}{*}{$\begin{array}{l}\text { Phase } 1 . \\
\text { Pre-research- } \\
\text { situational } \\
\text { analysis } \\
\text { (18 weeks) }\end{array}$} & $\begin{array}{l}\text { 1) Situational analysis } \\
\text { in four themes: tourism } \\
\text { development in regions } \\
\text { and domestic tourism; } \\
\text { tourism export; tourism } \\
\text { governance; } \\
\text { technologies and } \\
\text { digitalisation (desk } \\
\text { research; secondary } \\
\text { data) }\end{array}$ & Tourism researchers & $\begin{array}{l}\text { 1) Report on } \\
\text { situational analysis } \\
\text { of tourism } \\
\text { development in } \\
\text { Latvia } \\
\text { 2) Methodology for } \\
\text { stakeholders } \\
\text { involvement in } \\
\text { tourism planning }\end{array}$ \\
\hline & $\begin{array}{l}\text { 2) Analysis of the } \\
\text { governmental support } \\
\text { system and tools in } \\
\text { tourism (desk research; } \\
\text { secondary and primary } \\
\text { data) }\end{array}$ & Tourism researchers & $\begin{array}{l}\text { Report on the } \\
\text { governmental } \\
\text { support system on } \\
\text { tourism }\end{array}$ \\
\hline $\begin{array}{l}\text { Phase } 2 \text {. } \\
\text { Discussion of } \\
\text { issues and } \\
\text { development } \\
\text { of proposals } \\
\text { with industry } \\
\text { stakeholders (6 } \\
\text { weeks) }\end{array}$ & $\begin{array}{l}\text { 1) Discussions on } \\
\text { challenging issues in } \\
\text { tourism (strengths and } \\
\text { weaknesses) and future } \\
\text { developments } \\
\text { (4 regional and } 6 \\
\text { thematic focus groups) } \\
\text { 2) aggregation of focus } \\
\text { group results } \\
\text { (transcripts and visual } \\
\text { working material) }\end{array}$ & $\begin{array}{l}\text { Tourism researchers, } \\
\text { representatives of tourism } \\
\text { related governmental } \\
\text { bodies, other ministries, } \\
\text { planning regions, } \\
\text { municipalities, professional } \\
\text { and regional tourism } \\
\text { associations, NGOs, } \\
\text { tourism related clusters, } \\
\text { entrepreneurs and others. }\end{array}$ & $\begin{array}{l}164 \text { participants in } \\
\text { discussions } \\
\text { representing various } \\
\text { tourism stakeholder } \\
\text { groups. } \\
\text { Proposals for the } \\
\text { tourism development } \\
\text { plan. }\end{array}$ \\
\hline \multirow{2}{*}{$\begin{array}{l}\text { Phase } 3 . \\
\text { Elaboration, } \\
\text { debate and } \\
\text { improvement } \\
\text { of } \\
\text { development } \\
\text { plan } \\
\text { (23 weeks) }\end{array}$} & $\begin{array}{l}\text { Work on priorities, main } \\
\text { development directions } \\
\text { and activities for the } \\
\text { tourism development } \\
\text { plan (based on results of } \\
\text { focus groups and } \\
\text { research) }\end{array}$ & $\begin{array}{l}\text { Tourism researchers, } \\
\text { planning experts and } \\
\text { representatives of the } \\
\text { Ministry of Economics }\end{array}$ & $\begin{array}{l}\text { Draft of the tourism } \\
\text { development plan } \\
\text { 2021-2027. }\end{array}$ \\
\hline & $\begin{array}{l}\text { Debate on tourism } \\
\text { development priorities, } \\
\text { directions, activities, } \\
\text { responsible bodies and } \\
\text { performance } \\
\text { measurements }\end{array}$ & $\begin{array}{l}\text { Tourism researchers, } \\
\text { planning experts and } \\
\text { representatives of the } \\
\text { Ministry of Economics and } \\
\text { main tourism stakeholders } \\
\text { (planning regions, }\end{array}$ & $\begin{array}{l}\text { Proposals }(n=5) \text { to } \\
\text { improve the plan }\end{array}$ \\
\hline
\end{tabular}




\begin{tabular}{|l|l|l|l|}
\hline & & $\begin{array}{l}\text { municipalities, professional } \\
\text { and regional tourism } \\
\text { associations, NGOs, } \\
\text { tourism related clusters, } \\
\text { entrepreneurs and others. }\end{array}$ & \\
\cline { 2 - 4 } & Work on improvements & $\begin{array}{l}\text { Researchers and planning } \\
\text { experts }\end{array}$ & $\begin{array}{l}\text { Final versions of } \\
\text { tourism development } \\
\text { plan }\end{array}$ \\
\hline $\begin{array}{l}\text { Phase 4. } \\
\begin{array}{l}\text { Coordination } \\
\text { of the tourism } \\
\text { development } \\
\text { plan with other } \\
\text { governmental } \\
\text { bodies }\end{array}\end{array}$ & $\begin{array}{l}\text { Debate on concerted } \\
\text { actions }\end{array}$ & $\begin{array}{l}\text { Rinistry of Economics } \\
\text { (with 9 ministries e.g. The } \\
\text { Ministry of Environmental } \\
\text { Protection and Regional } \\
\text { Development, Ministry of } \\
\text { Transport, Ministry of } \\
\text { Culture; Ministry of Health, } \\
\text { Ministry of Education etc.) }\end{array}$ & $\begin{array}{l}\text { concerted actions } \\
\text { and incorporation of } \\
\text { activities related to } \\
\text { tourism development } \\
\text { in policy documents } \\
\text { of other institutions } \\
\text { and the National } \\
\text { Industry } \\
\text { Development Plan. }\end{array}$ \\
\hline
\end{tabular}

Researchers noted the following weaknesses of the pre-research phase: strictly defined research topics that limited the work of the researchers; a too short time frame for the implementation of primary research and a too broad field of study; lack of funding for primary research.

The pre-research phase enabled the aggregation and effective use of existing research results, identified a wider range of issues to be discussed and provided a good basis for developing proposals for the tourism development plan as well.

The interviewed representatives of the relevant public authorities evaluated the pre-research results as a significant complementary contribution to the process of developing and discussing the development plan, providing a sufficiently indepth situational analysis and a summary of trends. After the planning process, the report was appended as a supplement to the policy documents that justifies the need for the actions planned.

Evaluating the support mechanisms (MoE, 2019b), the state representatives emphasized that the scope and depth of the study was influenced by the lack of time, the fragmented information provided by the state institutions themselves and the lack of cooperation among institutions of different sectors. As a result, access to all necessary data was not provided. They also underlined the lack of a comprehensive impact assessment system of support mechanisms at national, regional and local level.

In the second phase of planning, in order to provide a bottom-up planning approach, the views of the stakeholders on the four issues raised were identified and ideas for tourism development actions for the next planning period were gathered. Over a period of six weeks 10 focus groups were organised with a total of 164 participants - representatives of tourism enterprises, regional and 
professional tourism associations, planning regions and municipalities, representatives of responsible and related ministries and public administration organizations such as the Latvian Association of Municipalities, the Ministry of Culture, the Ministry of Environmental Protection and Regional Development, the Latvian Investment Development Agency, the Nature Protection Board, etc.

Focus groups on regional tourism development issues were organised in the cities of four regions of Latvia - Kuldiga, Rezekne, Valmiera and Bauska. 162 participants were invited to participate in the focus groups, but 79 participants (attendance rate $48 \%$ ) representing the region's main tourism actors participated representatives of the planning region, regional tourism associations and the tourism network, municipal tourism specialists, managers of the most popular tourist attractions and the tourism industry. Researchers participating in these discussions noted that almost half of the participants invited came to the discussions, even though the discussion was organised at the beginning of the tourist season. The high participation rate was explained by the level of involvement of local actors in tourism and the fact that the tourism planning period coincided with the launch of the country's regional reform.

The discussions were also conducted in six thematic focus groups - business tourism, health tourism, cultural and nature tourism, technological solutions and tourism development, which took place in the capital Riga. 141 representatives of the tourism sector and other stakeholders were invited and 85 (attendance rate $60 \%)$ participated. The participants in business tourism group represented key stakeholders such as the Latvian and Riga Convention Offices, key organizers of international meetings, events and conventions, convention infrastructure providers, representatives of government institutions representing business tourism and other stakeholders. The health tourism group included representatives of the health tourism cluster, major exporters of medical services, representatives of the Ministry of Health and other stakeholders.

Analysing the transcripts of the regional and thematic focus groups, it is noted that the participants were successful in identifying the factors hindering the development of the tourism industry, pointing both to those directly related to the tourism industry and those indirectly, but vitally important for tourism development such as road quality, the bicycle path network, labour shortage and education, cross-sectoral cooperation, etc. However, some of the proposals were traditional, local and short-term in nature. The stance that tourism development was driven from above with state support could also be observed, which could be explained by the dominance of local governments in these discussions, the lack of leadership from companies and the lack of a business approach from tourism stakeholders. In one region, a clear stance could be noted that only state institutions were responsible for the failure of tourism development. 
The lowest participation rate was in the culture, nature and technology / digitization focus groups. These groups also had the fewest practical proposals for the development plan. This could be explained by the fact that the focus group was represented by players from different levels of the industry (from enterprise to ministry representatives), and that neither nature tourism nor cultural tourism has a strong industry lobby. The technology and digitization group was represented only by tourism enterprises, so the proposals focused on the micro level of the industry, which is explained both by the level of digitalisation of the enterprises themselves and the lack of knowledge about the development potential of smart destinations.

A state institution representative rated the industry's contribution to action development as mediocre, noting that, while the focus groups sought to involve the broadest possible range of industry stakeholders, the proposed solutions and future development directions lacked a comprehensive, strategic and innovative vision. Tourism governance at the regional and local level and the digitalisation of the sector were emphasised as the most significant issues. Digitization must be seen in the broader context of cross-sectoral and national digitalisation. It should be stressed that the focus groups did not raise the issue of sustainability.

During the third planning phase researchers in cooperation with MoE representatives responsible for tourism worked out a tourism development plan (2021-2027) (MoE, 2019c). It identified three development priorities: (1) strengthening the tourism industry's international competitiveness and promotion of exports (with 11 action directions); (2) development of attractive tourism offers in the context of local values and lifestyle, promotion of local tourism (6 action directions); (3) improving tourism management, education and research (3 action directions). All in all the action directions (total 20), activities to be implemented (total 101), institutions/organizations responsible, key cooperation partners, deadlines for implementing the activities, sources of resources needed and results to be achieved were identified for all priorities. The MoE in charge of tourism and the Latvian Investment Development Agency are responsible for the implementation of 69 activities and other parties are involved in 32 activities, such as the ministries (22 activities) - the Ministry of Environmental Protection and Regional Development (9 activities), Ministry of Culture, Ministry of Transport, Ministry of Education, professional associations, municipalities, the Riga international airport, the national airline. It illustrates the importance in tourism development of non-tourism institutions, which usually do not have tourismrelated issues in their policy documents and agendas.

The development plan was discussed in the Tourism Committee of the Economic Council of the $\mathrm{MoE}$ and was accessible to all stakeholders for four weeks in the e-environment for discussion. Comments and suggestions were subsequently received in writing. It should be noted that no substantive proposals 
for improvements were made. One piece of feedback strongly criticized the plan without any proposals for improvements. As the authors of the plan noted, such a negative reaction was due to the fact that the plan published did not include the situation analysis research of the sector causing difficultly in understanding of the need for particular action directions and activities. Difference in understanding (non-understanding) of some tourism related terms, such as tourism cluster, micro-clusters, health tourism, business tourism, etc. also cropped up during this phase.

The fourth phase of the plan involved the coordination of defined actions with the plans of other ministries by MoE staff, as a result of which these activities were incorporated into the medium-term plans of these institutions. The MoE spokeswoman noted that "due to the timely development of the tourism sector development plan and a detailed work plan, we were able to very precisely and specifically discuss with each institution the tourism industry needs and what we expect from them.... We actively represent the interests of the tourism industry, which to majority of these institutions is alien. In this process, we realized the need for closer collaboration and communication between the institutions, also regarding the implementation of what was planned.”

Evaluating the tourism planning process, the researchers involved in the process noted that it was generally viewed positively because, according to planning theory, the views of the various groups involved were clarified. However, given the profile, scale and interests of the various tourism enterprises and organizations involved, it should be borne in mind that sometimes there was no same-level discussion or solutions that positively affected the development of the whole sector. Tourism industry representatives, however, were not able to make any significant proposals for development in the fields of innovation, technology and digitalisation, which require a comprehensive approach and specific knowledge.

The MoE representative noted that this planning process clearly showed that how much contribution is made in the tourism sector at the national or local government level is unclear. It is therefore not possible to assess the potential returns of different actions. Productivity assessment must be one of the priorities when putting a development plan into practice. Cooperation between ministries and other institutions is essential for the successful development of the tourism industry. Experience shows that tourism authorities at the national level should proactively engage in dialogue with other institutions. On the other hand, tourism entrepreneurs and representatives of related institutions do not always have the competence to find the best solutions not only at the enterprise level but also in the long-term development of tourism at the national level. These areas need to be identified and solutions sought outside the industry. 
A deeper analysis of the document shows that not only traditional tourism development directions and activities are included, but new aspects of Latvian tourism development are highlighted as well. These are: targeted cooperation between destinations and their actors, strengthening the competitiveness of regional destinations; changes in the tourism management system, with a stronger role to be played at regional level, ensuring more effective communication and cooperation at local and national level; a focus on creating higher added value to the tourism products and strengthening export capacity not only at the enterprise but also at the industry level. For example, focus on medical and conference tourism or the creation of new, innovative tourism products. With regard to the introduction of technological solutions in enterprises and smart tourism destinations, enhancement of the level of digitalisation of companies is a direction that has so far been neglected by the industry.

\section{Conclusions}

The analysis of the process and content of the Latvian tourism development plan clearly reflects the use of an interactive or collaborative approach. Both the discussions during the development of the plan as well as the development directions and activities planned are based on the results of the cooperation among industry actors, which were based on the real environment and situation, and did not use a top-down approach, setting utopian, unattainable goals for the stakeholders.

Involving actors from the tourism industry at different levels in the planning process, it should be borne in mind that their competences in certain areas may be insufficient to provide strategic development solutions not only at enterprise or municipal level but also at national level. Therefore, it is important to involve both researchers and other experts in the planning process who can offer research and best practice based solutions. These consultants from other sectors and areas may be more neutral and reduce the dominance of the individual actors involved.

The tourism development plan has been developed in accordance with the principles of a collaborative approach, taking into account not only local interests but also EU guidelines (Manente et al., 2013).

Co-operation and competitiveness are the main development directions for the sector, but a transversal approach is directly in line with the shift in tourism development priorities in the EU (Panyik \& Anastasiadou, 2013). However, it should be noted that sustainability and productivity are not directly reflected in the activities included in the plan. This is to be ensured by selecting the projects to be supported and prioritizing the activities.

As a result of the tourism planning process, a logical and coherent tourism policy and proper implementation programme has been developed that avoids the 
overlapping of decision-making, fragmentation of actions and takes into account decisions and actions in other areas and purposefully integrates actions significant for tourism development in the policy documents of other institutions.

\section{References}

Altinay, L., \& Paraskevas, A. (2008). Planning research in hospitality and tourism. $2^{\text {nd }}$ ed. Oxford: Butterworth-Heinemann.

Council of the European Union [Council]. (2019). Council conclusions on the competitiveness of the tourism sector as a driver for sustainable growth, jobs, and social cohesion in the $E U$ for the next decade. Brussels: Council of the European Union. Retrieved from https://www.consilium.europa.eu/media/39512/st09707-en19.pdf

Dredge, D., \& Jamal, T. (2015). Progress in tourism planning and policy: A post-structural perspective on knowledge production. Tourism Management, 51, 285-297. DOI: 10.1016/j.tourman.2015.06.002

European Commission [EC]. (2010). Europe, the world's No 1 tourist destination - A new political framework for tourism in Europe. COM (2010) 352 final. Communication from the Commission to the European Parliament, the Council, the European Economic and Social Committee and the Committee of the Regions. Brussels: European Commission.

European Commission [EC]. (2018). Proposal for a regulation of the European Parliament and of the Council, COM (2018) 375 final. Strasbourg, European Commission.

Hall, C.M. (2008). Tourism planning: Policies, processes and relationships. 2nd ed. London: Prentice-Hall.

Hall, C.M. (2009). Archetypal approaches to implementation and their implications for tourism policy. Tourism Recreation Research, 34(3), 235-245.

Hall, C.M. (2011). A typology of governance and its implications for tourism policy analysis. Journal of Sustainable Tourism, 19(4-5), 437-457. DOI: 10.1080/09669582.2011.570346

Koshy, E., Koshy, V., \& Waterman, H. (2010). What is action research? In E. Koshy, V. Koshy, H. Waterman (Eds.), Action research in healthcare. London: SAGE Publications Ltd.

Liu, C.-H., Tzeng, G.-H., \& Lee, M.-H. (2012). Improving tourism policy implementation and the use of hybrid MCDM models. Tourism Management, 33(2), 413-426. DOI: 10.1016/j.tourman.2011.05.002

Manente, M., Minghetti, V., \& Montaguti, F. (2013). The role of the EU in defining tourism policies for a competitive destination governance. In C. Costa, E. Panyik, D. Buhalis (Eds.), Trends in European tourism planning and organization (pp. 208-219). Bristol: Channel View Publications.

Ministry of Economics [MoE]. (2014). Latvijas turisma attīstības pamatnostādnes 2014-2020. Riga: Ministry of Economics. Retrieved from https://www.em.gov.lv/lv/ nozares_politika/turisms/dokumenti/politikas_planosanas_dokumenti/

Ministry of Economics [MoE]. (2017). Informatīvs zinojums par Latvijas attīstības pamatnostādņu 2014.-2020. gadam istenošanas 2014.-2016. gada starpposma novērtējumu. Retrieved from

https://www.em.gov.lv/files/turisms/EMZin_181217_TUR_pamn_novert.pdf

Ministry of Economics [MoE]. (2019a). Latvijas tūrisma nozares analīze. Retrieved from https://www.em.gov.lv/files/turisms/Latvijas_turisma_nozares_analize_\%20BrandTour _\%20final.pdf 
Rozite et al., 2020. Tourism Policy in Latvia - from a Top-Down to a Collaborative Approach

Ministry of Economics [MoE]. (2019b). Esošo atbalsta instrumentu situācijas analīze un konceptuālu priekšlikumu izstrāde tūrisma nozares politikas pilnveidošanai. Retrieved from https://www.em.gov.lv/lv/nozares_politika/turisms/statistika_un_petijumi/ ekonomikas_ministrijas_petijumi_turisma_joma/

Ministry of Economics [MoE]. (2019c). Latvijas tūrisma attīstības rīcības plāns 2021. - 2027. gadam. Retrieved from

https://www.em.gov.lv/files/turisms/Turisma_ricibas_plans_2021_2027\%20BrandTour final\%20.pdf

O’leary, Z. (2004). Essential guide to doing research. London: SAGE Publications Ltd.

Panasiuk, A. (2019). Tourism management by public administration institutions. Scientific Journal of the Military University of Land Forces, 51(2/192), 364-376. DOI: 10.5604/01.3001.0013.2610

Panyik, C., \& Anastasiadou, C. (2013). Mapping the EU's evolving role in tourism: implications of the new EU tourism competence. In C. Costa, E. Panyik, D. Buhalis (Eds.), Trends in European tourism planning and organization (pp. 189-207). Bristol: Channel View Publications.

Saeima of the Republic of Latvia [Saeima]. (2010). Sustainable development strategy of Latvia until 2030. Riga: Saeima of the Republic of Latvia.

United Nations [UN]. (2015). Transforming our world: the 2030 agenda for sustainable development. NY: United Nations.

Winter, R., \& Munn-Giddings, C. (2001). A handbook for action research in health and social care. London: Routledge. 